Ana Pavlovic
Adjunct Professor
University of Bologna
Italy
Department of Industrial Engineering
Milan Sljivic
Full Professor
University of Banja Luka
Faculty of Mechanical Engineering
Bosnia and Herzegovina
Milija Kraisnik
Associate Professor
University of East Sarajevo
Bosnia and Herzegovina
Faculty of Mechanical Engineering
Jovica Ilic
Teaching Assistant
University of Banja Luka
Faculty of Mechanical Engineering
Bosnia and Herzegovina
Jelica Anic
Teaching Assistant
Faculty of Mechanical Engineering
Bosnia and Herzegovina

Ana Pavlovic

Adjunct Professor

Italy

Milan Sljivic

University of Banja Luka

engineering

Milija Kraisnik

niversity of East Sarajevo

Mechanical Engineering

Jovica llic

University of Banja Luka

Mechanical Engineering

Jelica Anic

of Mechanical Engineering Bosnia and Herzegovina

\section{Polymers in Additive Manufacturing: the Case of a Water Pump Impeller}

This research aimed at evaluating which of the polymers commonly used for rapid prototyping in the process of additive manufacturing can also meet the functional requirements in the preparation of final parts. In particular, the investigation was focused on a water pump impeller as a practical case study. A comparison between mechanical properties was proposed for this scope. ABSplus, ABS and PLA polymers were considered. Materials were tested in tensile and bending conditions. Results showed that ABSplus and ABS polymers satisfy all the mechanical requirements, while PLA fails. Then, the impellers were built-in and tested. All functional requirements, together with the necessary stability were verified. In this way, it was proved that, by selecting a suitable polymer, additive manufacturing can be successfully used to produce complex final elements, thus leading to extremely fast production, high accuracy and precision and even lower costs compared to other conventional technologies.

Keywords: mechanical properties, polymers: ABS, PLA, additive manufacturing, material extrusion, impeller

\section{INTRODUCTION}

Additive Manufacturing (AM), which has been quickly emerging as a promising technology-based technique for rapid prototyping of parts and products, is enabled to generate physical models directly from computer data (CAD). Without the use of tools or other accessories, $\mathrm{AM}$ is able to realize final products adding, directly, layer by layer. Thus, AM can reduce the time for prototyping, increasing the chance for a good placement on the market of successful products.

Classification, principles, characteristics, presence and potentiality of AM are presented in [1-6]. Some case studies also show how AM could be conveniently applied for the realisation of ready-to-market products. They are mainly focused on production costs and time, but also provide concerns on quality and functionality.

Anyway, before selecting this innovative technology for manufacturing functional parts and final products (instead of prototypes), a better knowledge on AM's materials, often relatively unknown, is preferable. Furthermore, this check has to be done considering the specific application where the final part is destined to.

This paper examines the mechanical characteristics of some of the most common polymers used in AM during a materials extrusion process, as Acrylonitrile Butadiene Styrene (ABS) and Polylactic Acid (PLA). In particular, it aims to determine which materials (between several options available of the market) meet all the technical requirements requested for the realisation of final parts.

Received: September 2016, Accepted: October 2016

Correspondence to: Ph.D Eng. Ana Pavlovic

Department of Industrial Engineering, Alma Mater

Studiorum University of Bologna, Italy

E-mail: ana.pavlovic@unibo.it

doi:10.5937/fmet1703354P

(C) Faculty of Mechanical Engineering, Belgrade. All rights reserved
A large number of experiments investigate the mechanical properties of 3D-printed materials.

For instance, in [7] four commercial photopolymer resins (known with the commercial names of FullCure720®, PA®, MK3® and VeroBlu®) are characterized. This research proves that the physical characteristics (e.g. presence of strong anisotropies) and nominal mechanical properties (e.g. tensile or bending strengths) provided by producers are generally valid. But it also suggests that a secondary and independent evaluation is preferable, considering that other aspects (e.g. aging, imbibition) can critically effect the material performance.

ABS is, probably, the most popular filament for AM. It is not very sensitive to temperature therefore a heated platform and an extruder must always be used. Anyway, ABS is preferred for applications where temperature is properly calibrated. According to [8], ABS represents the second filament in terms of easiness in working by 3D printing technology. ABSplus is a production-grade thermoplastic (by Stratasys), evolution of standard ABS, and it is ideal for manufacturing complex 3D models and prototypes in an office environment [9-11].

Alternative to ABS, PLA is becoming more and more present. It is a biodegradable thermoplastic, derived from corn starch and sugar cane. This material is environmentally friendly and safe to use [12-14].

In searching for better materials, [15] indicates that polyether-ether-ketone (PEEK) is superior respect to ABS, but its use by AM is not so immediate.

Finally, the influence of processing factors on the tensile strength of 3D-printed models are shown in [16].

\section{METHODS AND MATERIALS}

This investigation intends to compare several polymers, commonly used in AM, with the aim at defining an 
experimental procedure able to select the proper material for a given application. The research moves on two complementary levels:

- mechanical tests on materials

- functional tests on parts.

In particular, as already mentioned, ABS and PLA were selected for comparison. ABS was also proposed in terms of ABSplus. These three materials were used for producing either material specimens or final parts (the impellers).

The Fused Deposition Molding (FDM) process was adopted. Two different 3D printers were used (LeapFrog or Dimension Elite). Each printer provided a specific software for the elaboration of the geometries and the control of processes (respectively, Simplify $3 D$ or CatalystEX).

With the aim at creating samples and parts, these steps were followed:

- designing models by CAD software package;

- converting CAD models in .STL, a standard data format recognized by the $3 \mathrm{D}$ printers;

- $\quad$ transferring the .STL files to the IT platforms used for controlling and optimizing the 3D printing;

- elaborating the .STL files in the way to optimize process settings;

- $\quad$ creating the 3D physical models by 3D printers

- $\quad$ surface finishing of the models.

\subsection{Water pump impeller additive manufacturing}

The impeller was realized in ABSplus by the use of a professional 3D printer Dimension Elite and the CatalystEX software for process controlling (Figure 1).

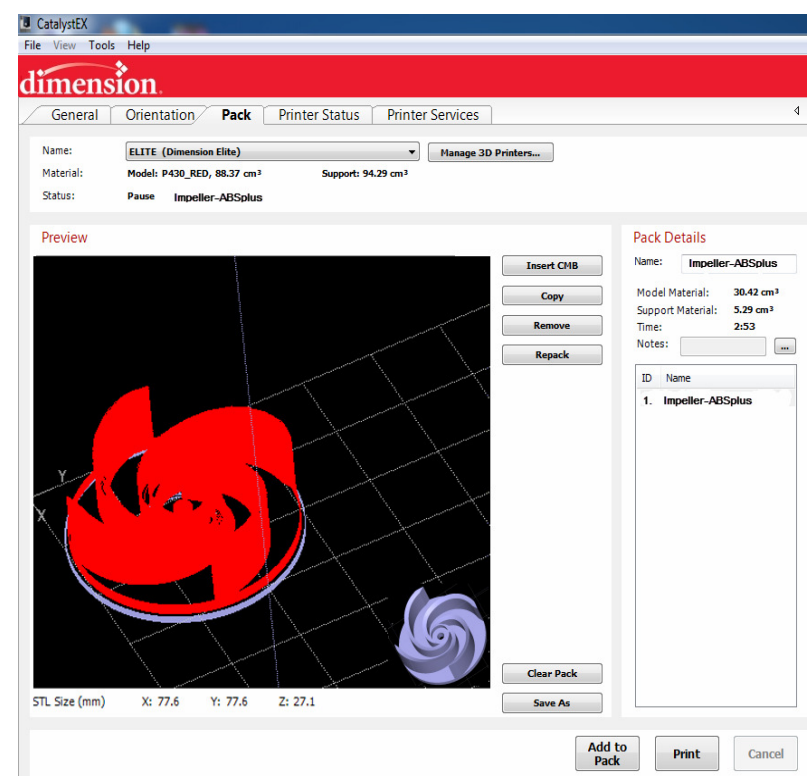

Figure 1. Processing the impeller in ABSplus by CatalystEX software

The ABS impeller was produced on the consumer grade 3D printer LeapFrog. Optimization and processing of influential parameters was performed in Simplify3D software, Figures 2.

Using LeapFrog 3D printer, an impeller in PLA polymer was also produced. The geometrical processing and the selection of the technological parameters was performed in Simplify3D software, according to the chemical and mechanical properties of the $1.75 \mathrm{~mm}$ diameter PLA filament used, Figure 3.

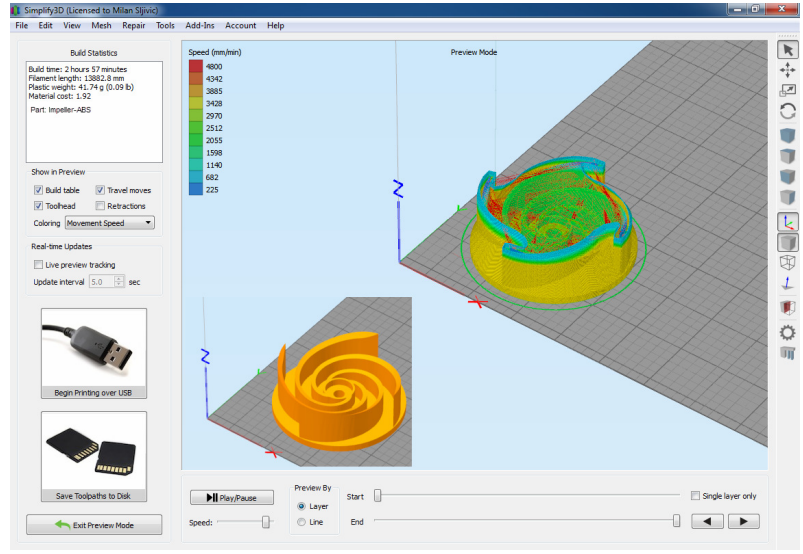

Figure 2. ABS impeller in Simplify3D software

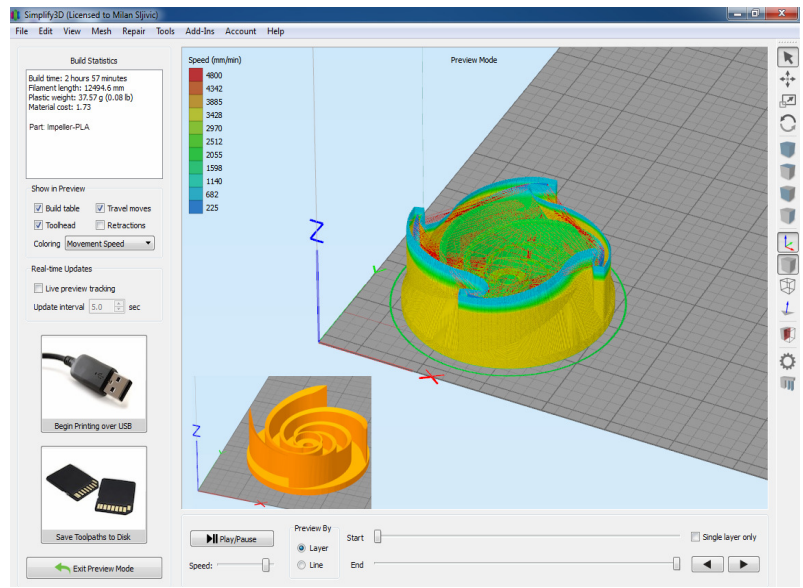

Figure 3. Processing of impeller in PLA by Simplify3D software

After producing the impeller on 3D printers, postprocessing, i.e. additional activity on removing support material was carried out and finished parts are shown in Figure 4.

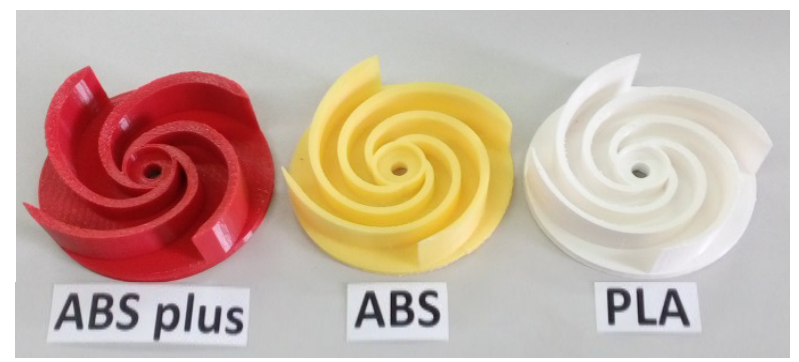

Figure 4. Impellers made from ABSplus, ABS, and PLA

\subsection{Specimens additive manufacturing}

In order to determine mechanical characteristics of materials, standard procedures relating to tensile (EN ISO 527-1 and EN ISO 527-2) and three point bending (ISO 178) testing were applied. The tests were carried out on samples whose dimensions are given in Figure 5.

Eight specimens per each material and each test condition were realized (Figure 6 and 7). Equipment and process parameters were the same adopted during the impellers manufacturing. 


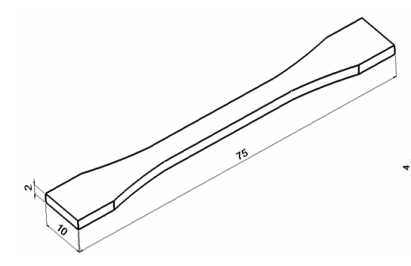

a)

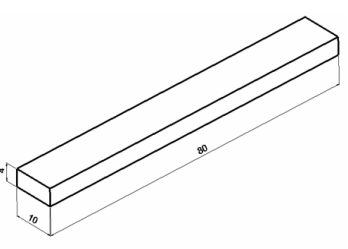

b)
Figure 5. Standard samples for testing: a) tensile and b) three point bending.

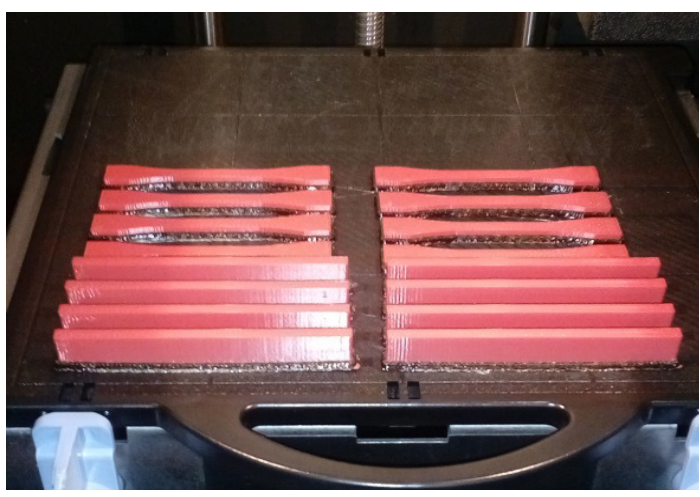

Figure 6. 3D printing of specimens in ABSplus using the Dimension Elite 3D printer platform.

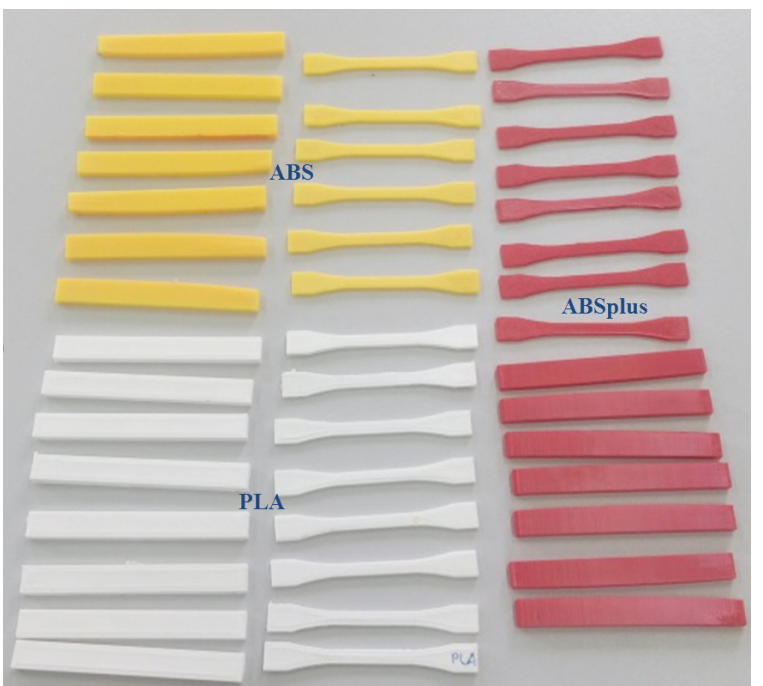

Figure 7. Specimens from ABSplus, ABS and PLA

\section{EXPERIMENTS}

\subsection{Tensile test}

A Shimnadzu AGS-20 kN NXD testing machine (Figure 8) and strain rate of $5 \mathrm{~mm} / \mathrm{min}$ were used. ABSplus and ABS specimens between the machine jaws during tensile tests and fails are shown in Figure 9.

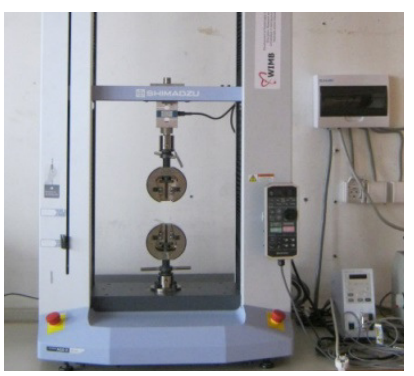

Figure 8. Testing machine for tensile and bending tests
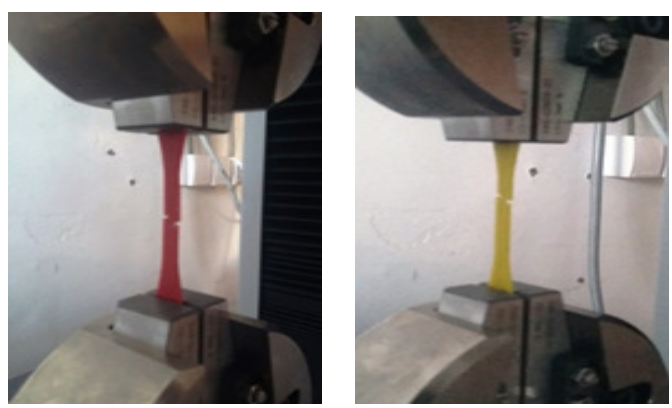

Figure 9 a) ABS and b) ABSplus specimens

a)

b)

c)

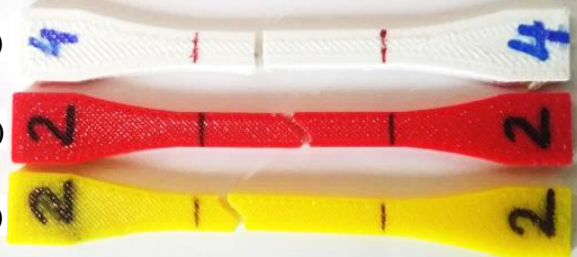

Figure 10. a) PLA, b) ABSplus and c) ABS specimens after failure

With the aim to process and graphically display the measures, Trapezium $\mathrm{X}$ software was used. Initial size of specimens and test conditions are considered.

The $\sigma-\varepsilon$ (Engineering stress - Engineering strain) diagrams for ABSplus, ABS and PLA polymers are shown in, respectively, Figures 11, 12 and 13.

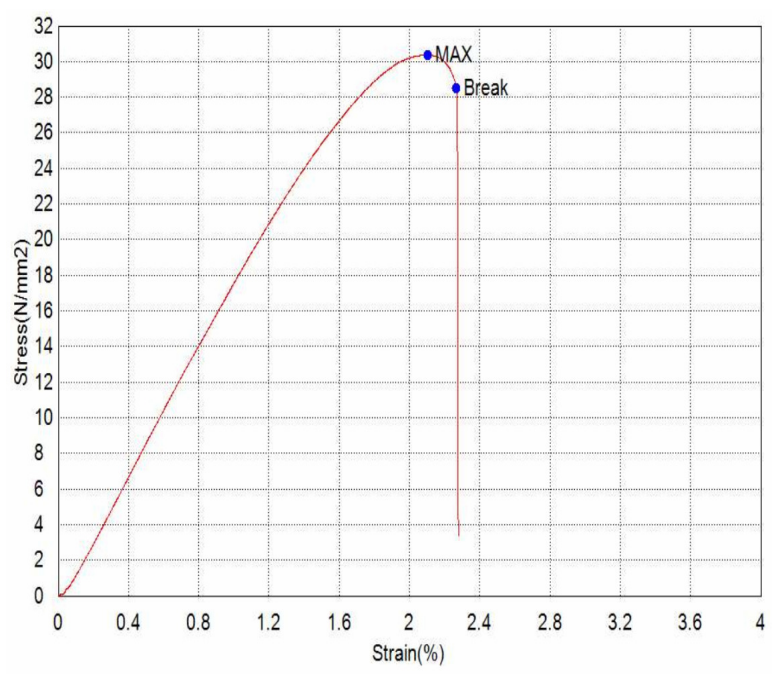

Figure 11. Tensile stress-strain curve for ABSplus

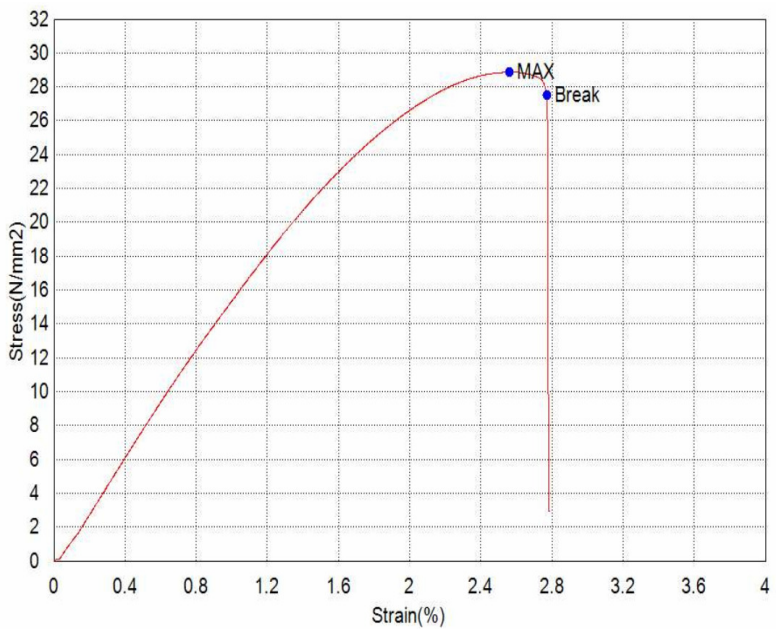

Figure 12. Tensile stress-strain curve for ABS 


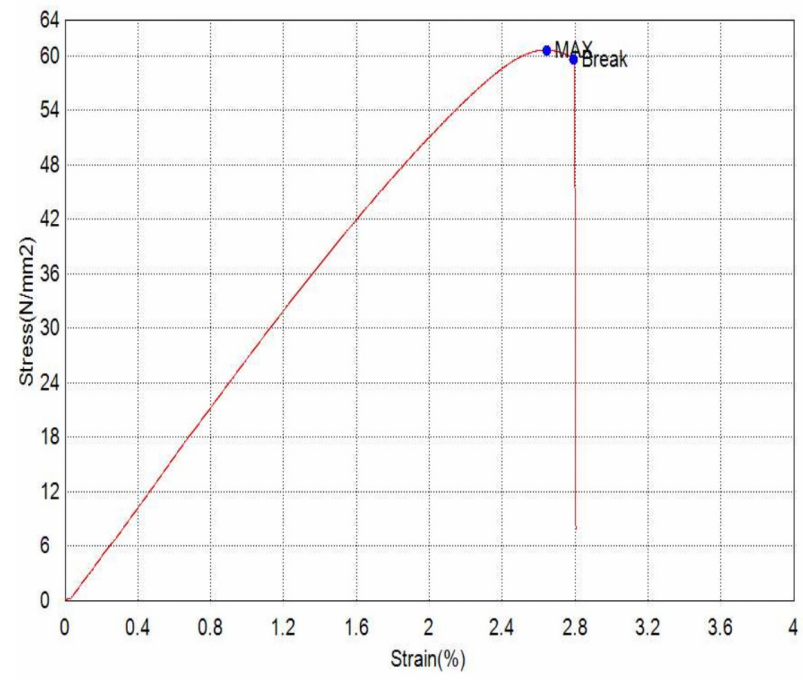

Figure 13. Tensile stress-strain curve for PLA

The mean values of tensile strength $R_{M}$ and maximum deformation $\varepsilon_{M}$ were determined and shown in Figures 14 and 15, respectively.

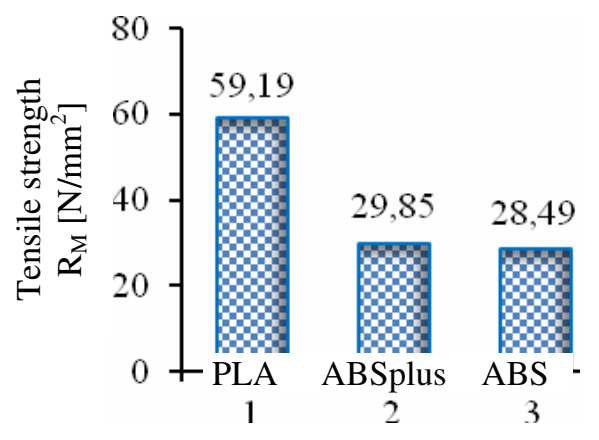

Figure 14. Mean values of tensile strength

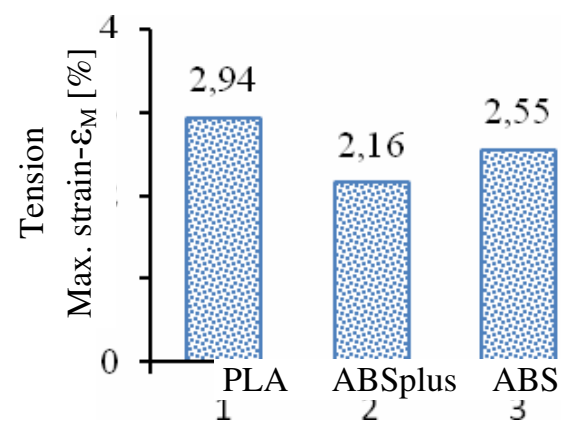

Figure 15. Mean values of maximum tensile deformation

\subsection{Three-points bending test}

With the aim at determining the flexural strength, five specimens for each material were analysed by flexural tests (Figure 16). The same Shimnadzu AGS-20 kN NXD testing machine and strain rate of $5 \mathrm{~mm} / \mathrm{min}$ were used. A $5 \mathrm{~mm}$ radius tool permitted to perform the three point test.

According to standards, the distance between the supports is determined by the dimensions of specimens. Considering a specimens' thickness $\mathrm{s}=4 \mathrm{~mm}$, the distance between supports amounted to $\mathrm{L}=64 \mathrm{~mm}$. Specimens after failure are shown in Figure 16. Flexural stress-strain diagrams are shown in Figures 17-19.

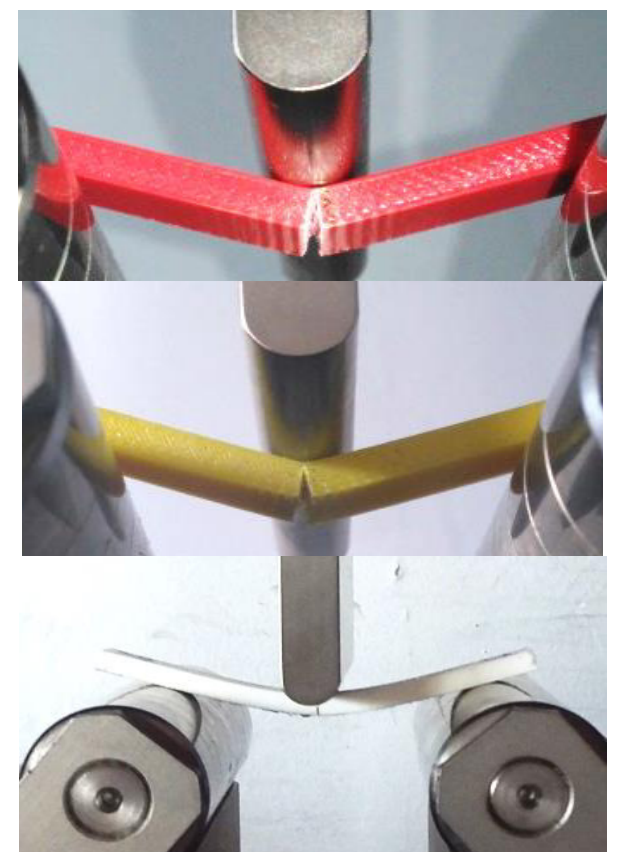

Figure 16. Fracture of specimens in a) ABSplus, b) ABS and c) PLA

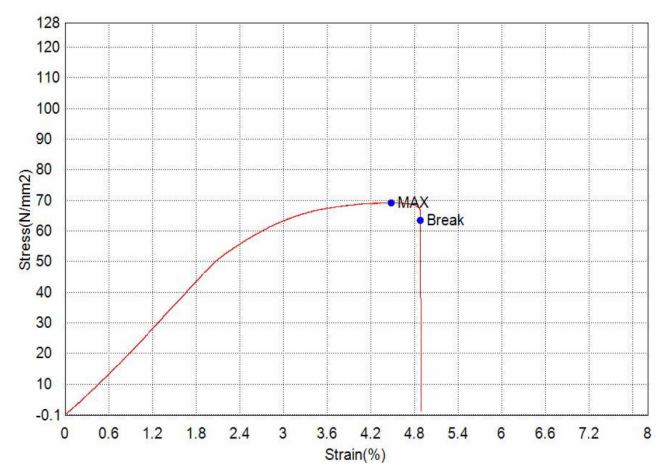

Figure 17. Bending stress-strain curve using ABSplus

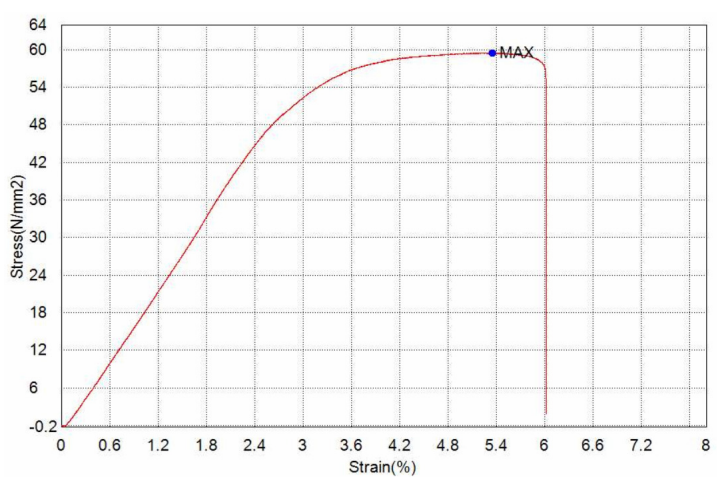

Figure 18. Bending stress-strain curve using ABS

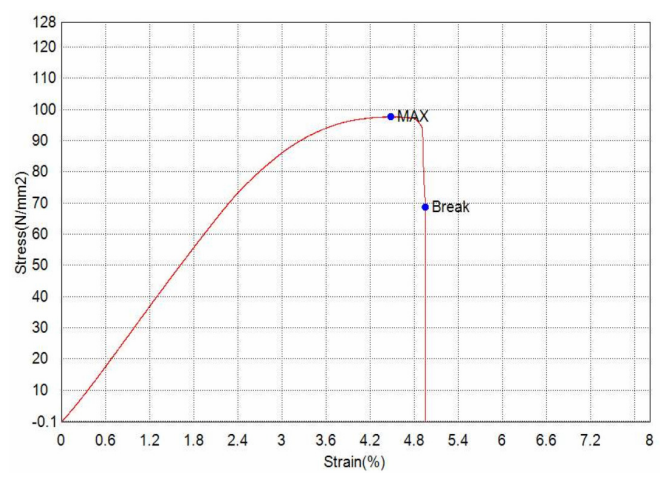

Figure 19. Bending stress-strain curve using PLA 
The mean values of the flexural strength and maximum strain are shown in Figure 20 and Figure 21.

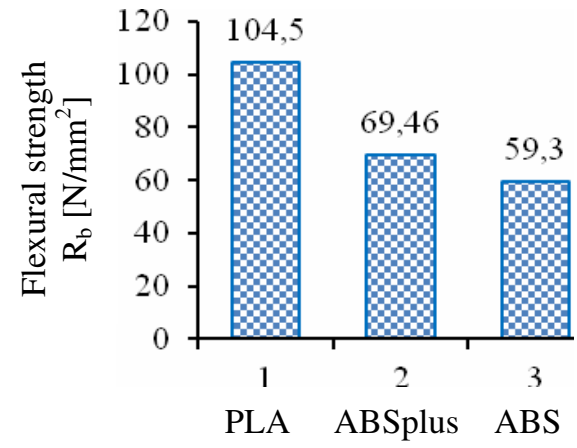

Figure 20. The mean values of flexural strength

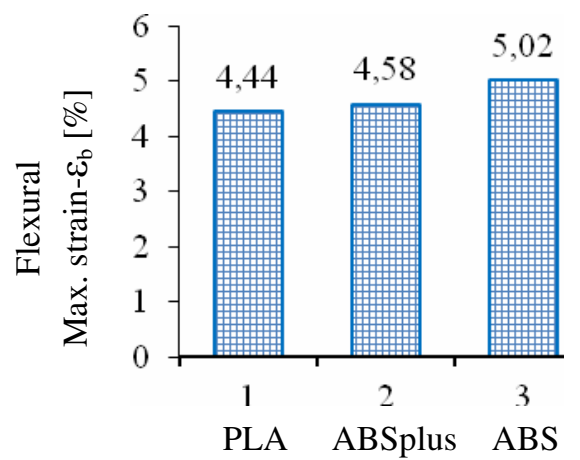

Figure 21. The mean values of maximum flexural strain

\section{RESULTS}

This experimental investigation highlighted the different mechanical behaviour of polymers used for AM.

According to Figure 11-13, the tensile strength of ABS and ABSplus is approximately the same, but it is about 50\% lower than PLA. In tensile test, PLA showed greatest strength.

Referring to the tensile strain, it is known that a preliminary assessment of ductile properties of the polymer can be performed based on the maximum value of equal deformation. In this respect, it can be concluded that the results for all polymers are quite similar, since differences in values are less than $1 \%$. However, numerically speaking, PLA exhibits the greatest tensile strain.

Regarding the flexural tests, measures highlight that the ability of forming polymers are correlated with the flexural strength. In particular, PLA presents the highest flexural strength. However, ductile properties are least shown, which led to complete physical separation of material during the test. On the other hand, ABSplus and, especially, ABS can accumulate a larger amount of energy before fracture, which affects the ultimate strain.

In general, all the polymers under investigation showed a greater strength and better ultimate strain in the case of flexure respect of tension.

Based on the overall results, it can be concluded that PLA presents the highest strength, while its ductility significantly depend on the direction of external loads. Strength and ductility for ABSplus and ABS are quite similar. Anyway, ABSplus appears stronger in comparison to $\mathrm{ABS}$, but with an ultimate strain less pronounced.
The analysis of the final parts, performed on the water pump impellers, shows that parts' quality are strongly related to the specific polymer, but also to the 3D printer used. The best surface quality and mechanical properties are achieved on the Dimension Elite (Stratasys), the FDM professional printer with ABSplus polymer (Figure 1). In particular, this impeller seems to be appropriate for its direct utilisation in applications. At the same time, this process solution deals with biggest costs. The costs of quality model material (Stratasys Model Cartridge: $1 \mathrm{~kg} \approx \$ 250$ ) and support material (Stratasys Support Cartridge: $1 \mathrm{~kg} \approx \$$ 250) are higher.

The main parameters that define the optimal production of the impeller are as follows: Build time: 2 hours 53 minutes, Model material $=30.42 \mathrm{~cm}^{3}$, Support material $=5.29 \mathrm{~cm}^{3}$, Layer thickness $=0.254 \mathrm{~mm}$.

The quality of impellers made of ABS and PLA by a LeapFrog consumer grade 3D printer (Figures 2 and 3) can also be considered as acceptable, considering the traditional limits of the rapid prototyping processes. At the same time, flexural tests on PLA showed a complete destruction of specimens immediately after reaching the maximal flexural strength. This extreme brittleness makes PLA inappropriate for real components.

With regard to the mechanical properties, ABS seems to represent a good material solution, similarly to ABSplus. Thus, an impeller in ABS could be also recommended as final choice. The main difference between ABS and ABSplus deals with costs. The cost of the material used on LeapFrog consumer grade 3D printer is as follows: Model material $(1 \mathrm{~kg} \approx \$ 30)$ and Support material $(1 \mathrm{~kg} \approx \$ 30)$, which is beneficial for the lower quality that can be achieved with this material.

\section{CONCLUSION}

The experimental evidences presented in this paper may serve as the basis for an adequate choice of polymer materials in the process of Additive Manufacturing as well as suggestions for the choice of an appropriate 3D printer.

Furthermore, some practical suggestions may be generally given regarding the selection of materials for FDM processes. Firstly, because of higher ductility and toughness, ABSplus and ABS are advantageous for making parts that work in varying operating conditions which result in the generation of complex stress states. Secondly, due to significant lower cost of materials in relation to professional printers, the choice of consumer grade 3D printer can be suggested for making impellers, but only if ABS is selected.

Since PLA brittleness, this material could be used to produce final parts facing predominantly axial loads, but they are not surely recommendable for impellers. At the same time, since PLA is a biodegradable and relatively high quality in printing can be achieved, this material is suitable for models realized by consumer grade 3D printers and with limited functional requirements.

\section{ACKNOWLEDGMENT}

This paper is realized as part of AdriaHub project [17], inside the framework of the European IPA program. 


\section{REFERENCES}

[1] ASTM International Designation: F2792-12A; Standard Terminology for Additive Manufacturing Technologies, DOI: 10.1520/F2792-12A.

[2] Wohlers Report 2014: 3D Printing and Additive Manufacturing, State of the Industry, Annual Worldwide Progress Report, WOHLERS ASSOCIATES, INC. Colorado 80525 USA.

[3] Gibson, I. et al.: Additive Manufacturing Technologies, Springer Science + Business Media New York 2015, DOI 10.1007/978-1-4939-2113-3_2.

[4] Grenda, E.: Printing the future, The 3D printing and rapid prototyping source book, Third Edicion, CASTLE ISLAND CO.ARLINGTON, MA 02474 U.S.A.http://home.att.net/ castleisland/

[5] Grujovic, N., Pavlovic A., Sljivic, M., and Zivic, F.: Cost optimization of additive manufacturing in wood industry, FME Transactions (2016) 44, 386392.

[6] Grujović, N., Borota, J., Šljivić, M., Divac, D., and Rankovi, V.: Art and design optimized 3D printing, 34th International Conference on Production Engineering, Niš, 2011, p.p.

[7] Fragassa, C., Minak, G., Poodts, E.: Mechanical characterization of photopolymer resins for raid prototyping, paper presented at the 27th DanubiaAdria Symposium on Advances in Experimental Mechanics, DAS, 2010.

[8] Talić, A., Durmić, A., Šljivić, M., and Stanojević, M.: The Process of Developing Conceptual Design of a Product Using Rapid Prototyping Technology, 18th International Research/Expert Conference TMT 2014, Budapest, Hungary 10-12 September, 2014

[9] Ahn, S., Montero, M., Odell, D., Roundy, S., and Wright, P.K.: Anisotropic material properties of fused deposition modeling ABS. Rapid Prototyp. J. 2003, 8, 248-257.

[10] Gibson, I., Rosen, D.W., and Stucker, B. Eds. (2010), Additive Manufacturing Technologies (Rapid Prototyping and Direct Digital Manufacturing), Chapter 2.6, page 27-28, Springer Science + Business Media, LLC, New York, USA, 2010., DOI 10.1007/978-1-4419-1120-9

[11]Liou, F. W. (2008), Rapid Prototyping and Engineering Applications (A Toolbox for Prototype Development), Chapter 6. Rapid Prototyping Processes: Liquid-Based, Solid Based, Powder Based; page: 215-, CRC Press, Taylor \& Francis Group, 6000 Broken Sound Parkway, USA, ISBN13: 978-0-8493-3409-2.
[12] Durgun, I.: Ertan, R. Experimental investigation of FDM process for improvement of mechanical properties and production cost. Rapid Prototyp. J. 2014, 20, 228-235.

[13]Bigg, D.M. Mechanical properties of particulate filled polymers. Polym. Compos. 1987, 8, 115-122.

[14] Rašuo, B.: Aircraft Production Technology, Faculty of Mechanical Engineering, University of Belgrade, Belgrade, 1995, (in Serbian).

[15] Wenzheng, W. et al.: Influence of Layer Thickness and Raster Angle on the Mechanical Properties of 3D-Printed PEEK and a Comparative Mechanical Study between PEEK and ABS, Materials 2015, 8, 5834-5846; doi:10.3390/ma8095271.

[16] Galeta, T., Kladaric, I., and Karakas, M,: Influence of processing factors on the tensile strength of 3Dprinted models, MTAEC9, 47(6)781(2013), UDK 621.7:004.896, ISSN 1580-2949.

[17] Savoia, M., Stefanovic, M., and Fragassa, C.: Merging Technical Competences and Human Resources with the Aim at Contributing to Transform the Adriatic Area in Stable Hub for a Sustainable Technological Development, International Journal of Quality Research, Vol.10, No.1, pp: 1-16, 2016

\section{ПОЛИМЕРИ У АДИТИВНОЈ ПРОИЗВОДЫИ: СЛУЧАЈ ПОКРЕТАЧА ПУМПЕ ЗА ВОДУ}

\section{А. Павловић, М. Шљивић, М. Краишник, Ј. Илић, Ј. Анић}

Ово истраживање има за циљ евалуацију који између полимера који се обично користе за брзу израду прототипова у процесу адитвне производње може да задовољи функционалне захтеве у припреми завршних делова. Посебно, истрага је фокусирана на покретач пумпе за воду као практичан пример примене. Поређење механичких карактеристика предложен је за ове области. ABSplus, ABS и PLA полимери су разматрани. Материјали су тестирани на затезање и савијање. Резултати су показали да ABSplus и ABS полимери задовољавају све механичке захтеве, док PLA не. Затим, покретач пумпе је уграђен и тестиран. Сви функционални захтеви, заједно са потребном стабилношћу су верификовани. На овај начин, доказано је да, одабиром одговарајућег полимера, адитивна производња може се успешно користити за производњу комплексних заврчних елемената, што доводи до остваривања екстремно брзе производње, високе тачности и прецизности и мањих трошкова у поређењу са другим конвенционалним технологијама. 